\title{
Efficacy In Vitro of Caffeine and Valproic Acid on Patient-Derived Undifferentiated Pleomorphic Sarcoma and Rhabdomyosarcoma Cell Lines
}

\author{
KENTARO IGARASHI ${ }^{1,2,3}$, KEI KAWAGUCHI ${ }^{1,2}$, TASUKU KIYUNA ${ }^{1,2}$, TAKASHI MURAKAMI ${ }^{1,2}$, \\ SHINJI MIWA ${ }^{3}$, SCOTT D. NELSON ${ }^{4}$, SARAH M. DRY ${ }^{4}$, YUNFENG LI $^{4}$, ARUN S. SINGH ${ }^{5}$, \\ HIROAKI KIMURA $^{3}$, KATSUHIRO HAYASHI ${ }^{3}$, NORIO YAMAMOTO ${ }^{3}$, \\ HIROYUKI TSUCHIYA ${ }^{3}$, FRITZ C. EILBER ${ }^{6}$ and ROBERT M. HOFFMAN ${ }^{1,2}$ \\ ${ }^{1}$ AntiCancer, Inc., San Diego, CA, U.S.A.; \\ ${ }^{2}$ Department of Surgery, University of California, San Diego, CA, U.S.A; \\ ${ }^{3}$ Department of Orthopaedic Surgery, Kanazawa University, Kanazawa, Japan; \\ ${ }^{4}$ Department of Pathology, University of California, Los Angeles, CA, U.S.A; \\ ${ }^{5}$ Division of Hematology-Oncology, University of California, Los Angeles, CA, U.S.A; \\ ${ }^{6}$ Division of Surgical Oncology, University of California, Los Angeles, CA, U.S.A.
}

\begin{abstract}
Background/Aim: We have previously reported that caffeine $(C A F)$ can enhance chemotherapy efficacy of bone and soft-tissue sarcoma established cell lines via cell-cycle perturbation. We subsequently tested the combination of valproic acid (VPA), a histone deacetylase (HDAC) inhibitor, with caffeine on established human osteosarcoma cells in vitro. Both VPA and CAF caused concentration-dependent cell death of the osteosarcoma cell lines in vitro, and their combination was synergistic. We subsequently established patient-derived cell lines from undifferentiated pleomorphic sarcoma (UPS) and rhabdomyosarcoma (RMS), both of which are recalcitrant cancers. These cell lines are termed AC-UPSO1 and AC-RMSO1, respectively. Materials and Methods: In the present study, we tested CAF and VPA and their combination on the two patientderived sarcoma cell lines. Cell survival after a $72 \mathrm{~h}$ exposure to each drug was determined by the WST-8 assay. IC 50 values were calculated for each drug. Results: CAF and VPA caused
\end{abstract}

Correspondence to: Prof. Robert M. Hoffman, AntiCancer, Inc., 7917 Ostrow Street, San Diego, CA 92111, U.S.A. Tel: 858-654-2555, Fax: +1 8582684175, e-mail: all@anticancer.com or Prof. Fritz C. Eilber, UCLA, Division of Surgical Oncology, 10833 LeConte Avenue, Rm. 54-140 CHS, Los Angeles, CA 90095-1782, U.S.A. Tel: 310-8257086, Fax: +1 3108257575, e-mail: fceilber@mednet.ucla.edu or Prof. Hiroyuki Tsuchiya, Department of Orthopaedic Surgery, Graduate School of Medicine, Kanazawa University, 13-1 Takaramachi, Kanazawa 920-8641, Japan. Tel: +81-76-265-2374, Fax: +81 762344261,e-mail: tsuchi@med.kanazawa-u.ac.jp

Key Words: Undifferentiated pleomorphic sarcoma, UPS, rhabdomyosarcoma, RMS, patient-derived cell lines, caffeine, valproic acid, cell kill, synergy. concentration-dependent cytocidal efficacy for both cell lines. The $I C_{50}$ for CAF for AC-UPSO1 was $2.02 \pm 0.22 \mathrm{mM}$. The $I C_{50}$ for VPA for AC-UPSO1 was $9.54 \pm 1.44 \mathrm{mM}$. The $I_{50}$ for $C A F$ for AC-RMSO1 was $2.37 \pm 0.48 \mathrm{mM}$. The $I_{50}$ for VPA for $A C$ RMSO1 was $2.13 \pm 0.20 \mathrm{mM}$. Synergistic efficacy of combination treatment of CAF and VPA was also observed for both cell lines. Conclusion: The results of the present study suggest that CAF and VPA may be useful in the treatment of recalcitrant sarcoma.

Caffeine (1,3,7-trimethylxanthine) (CAF) has been used to enhance cancer chemotherapy. CAF has several anti-tumor effects, such as apoptosis induction (1). CAF can also modulate the cell cycle of cancer cells. Time-lapse imaging of HeLa cells expressing a fluorescent ubiquitination-based cell cycle indicator (FUCCI) in the nucleus, showed that caffeine increased efficacy of cisplatinum (CDDP) on 143B human osteosaroma cells by increasing the mitotic rate which subsequently increased apoptosis. Caffeine overcame the cell-cycle arrest at $\mathrm{S} / \mathrm{G}_{2}$ induced by $\mathrm{CDDP}$, allowing mitosis to proceed, thereby increasing its efficacy (2).

Valproic acid (VPA) is a histone deacetylase (HDAC) inhibitor that also has potential anti-cancer efficacy, shown in clinical trials for leukemia (3), lung cancer (4), and glioblastoma $(5,6)$.

Sarcomas are a very heterogenetic group of recalcitrant cancers. Previously, we demonstrated cell killing by CAF and VPA and their combination on long-established, high-passage human osteosarcoma cell lines MG63, 143B, and SaOS2 (7). Both VPA and CAF caused concentration-dependent cell death of the osteosarcoma cell lines in vitro. We have also previously reported that CAF-modulation chemotherapy improved the treatment of bone and soft tissue sarcoma in the clinic (8-13). 
Previously a patient with high grade undifferentiated pleomorphic soft-tissue sarcoma (UPS) from a striated muscle was implanted orthotopically in the right biceps femoris muscle of mice to establish a patient-derived orthotopic xenograft (PDOX) model (14). A patient-derived orthotopic xenograft (PDOX) mouse model of rhabdomyosarcoma (RMS) was also previously established orthotopically in the right biceps femoris muscle and right quadriceps muscle of nude mice (15).

In the present study, we determined if there was synergistic efficacy of the combination of CAF and VPA against patient-derived UPS and RMS cell lines obtained from the above-described PDOX models.

\section{Materials and Methods}

Chemicals. VPA and CAF were obtained from Wako Pure Chemical Industries, Ltd. (Osaka, Japan). CAF and VPA were both dissolved in and diluted with phosphate-buffered saline (PBS). The stock solution for CAF was $25 \mathrm{mM}$. The stock solution for VPA was $30 \mathrm{mM}$.

Cell lines. Patient-derived AC-UPS01 and AC-RMS01 cell lines were established from UPS (14) and RMS (15) PDOX mouse models, respectively. The cell lines were grown in RPMI 1640 medium with $10 \%$ fetal calf serum. The cell lines were used in passages 5 to 10 . Previously, informed-consent was obtained by the patient donors under a UCLA Institutional Review Board-approved protocol (IRB \#10-001857) $(14,15)$.

Growth inhibition assay. Cellular viability was assessed using the WST-8 dye reduction assay. Cells were seeded in 96-well flatbottomed microplates $(100 \mu \mathrm{l} / \mathrm{well})$ at a $5 \times 10^{4}$ cells $/ \mathrm{ml}$ density, incubated at $37^{\circ} \mathrm{C}$ for $24 \mathrm{~h}$, and exposed to various concentrations of test compounds for $72 \mathrm{~h}$. For each concentration, at least 8 wells were used. After incubation with the test compounds, $10 \mu \mathrm{l}$ WST- 8 solution was added to each well. The microplates were further incubated for $3 \mathrm{~h}$ at $37^{\circ} \mathrm{C}$, and absorption was measured using a microprocessorcontrolled microplate reader (Sunrise ${ }^{\mathrm{TM}}$; TECAN, San Joes, CA, USA) at $450 \mathrm{~nm}$. Cell-survival was calculated as the percentage of live cells with respect to untreated control cells. $\mathrm{IC}_{50}$ values were derived from concentration-response curves.

Calculation of Combination Index $(C I)$. The specific interaction between caffeine and valproic acid on the patient-derived UPS and RMS cell lines was evaluated by the combination index (CI) assay using the CalcuSyn software from ComboSyn Inc. (New Jersey, USA) with the method used by Chou and Talalay (16). In this analysis, synergy was defined as a $\mathrm{CI}<1.0$, antagonism as a $\mathrm{CI}$ $>1.0$, and additivity as CI values not significantly different from 1.0.

\section{Results and Discussion}

Efficacy of caffeine (CAF) and valproic acid (VPA) on patientderived undifferentiated pleomorphic sarcoma (UPS) and rhabdomyosarcoma (RMS) cell lines. The cytotoxic activity of CAF and VPA was determined on the patient-derived UPS (ACUPS01) and RMS (AC-RMS01) cell lines. Cells were incubated for $72 \mathrm{~h}$ with each compound. Cell survival was evaluated as

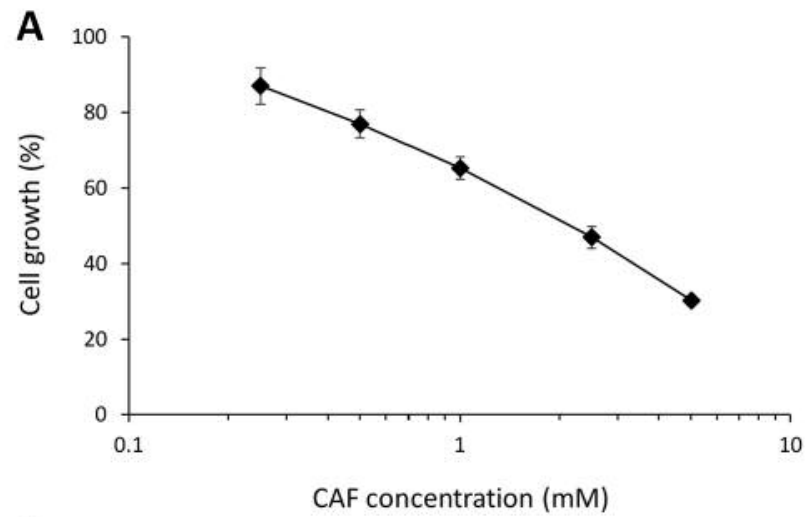

B

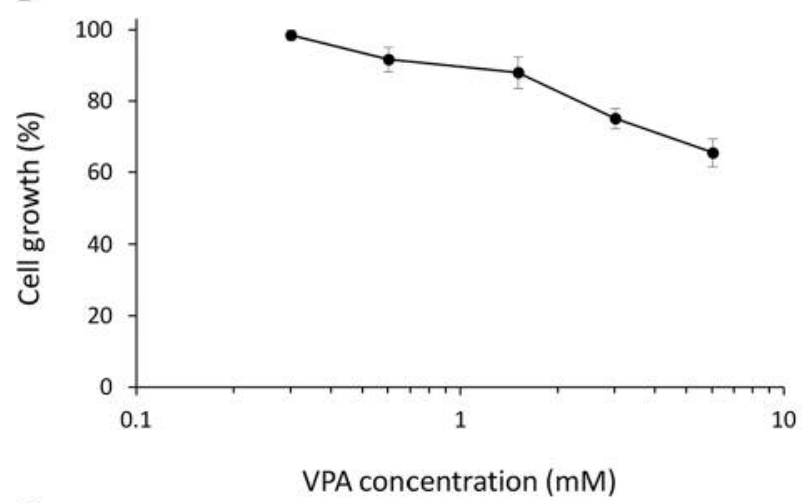

C

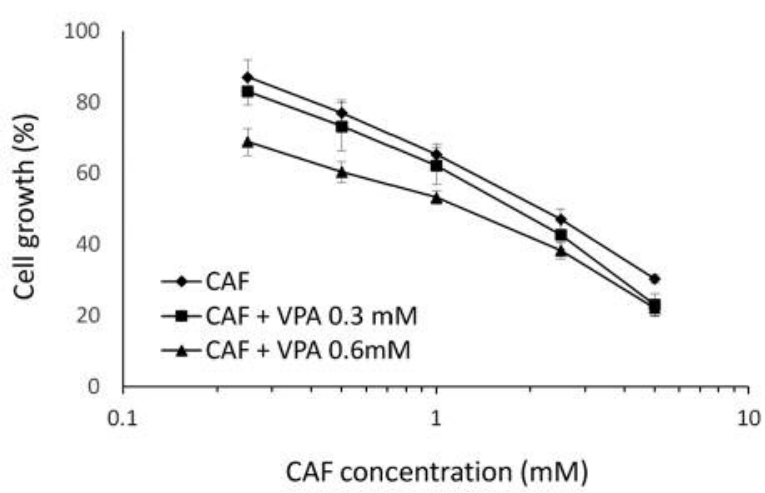

Figure 1. Growth inhibitory activity of caffeine $(C A F)$ and valproic acid (VPA) or their combination on the patient-derived undifferentiated pleomorphic sarcoma (UPS) AC-UPSO1 cell line. Cells were incubated with each drug or their combination for $72 \mathrm{~h}$. Viability was determined with the WST-8 assay. Experimental details are provided in the Materials and Methods. (A) Growth-inhibitory activity of CAF against AC-UPSO1 cells. (B) Growth-inhibitory activity of VPA against AC-UPSO1 cells. (C) Growth inhibitory activity of CAF combined with VPA against AC-UPSO1 cells.

described in the Materials and Methods. CAF and VPA significantly inhibited the patient-derived UPS (Figure 1) and RMS (Figure 2) cell lines in a dose-dependent manner. The $\mathrm{IC}_{50}$ for CAF for AC-UPS01 was $2.02 \pm 0.22 \mathrm{mM}$. The $\mathrm{IC}_{50}$ for CAF for AC-RMS01 was $2.37 \pm 0.48 \mathrm{mM}$. The AC-UPS01 and ACRMS01 cell lines had a similar sensitivity to CAF ( $p=0.1045)$. 


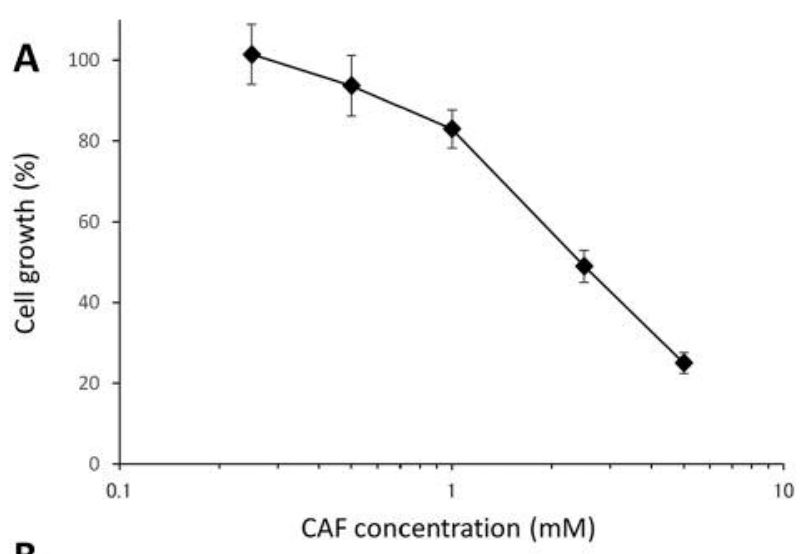

B

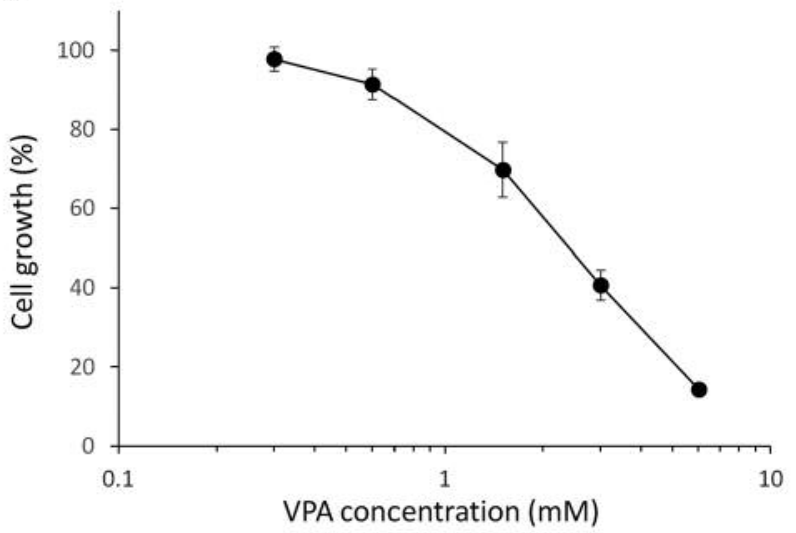

C

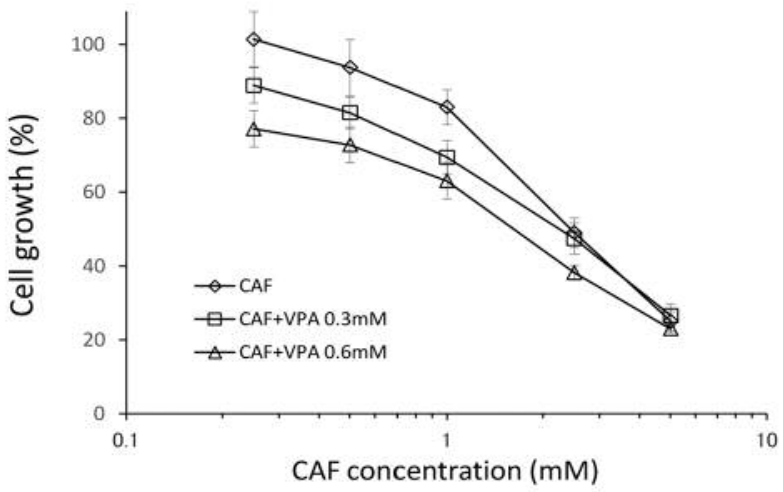

Figure 2. Growth inhibitory activity of CAF and VPA or their combination on the patient-derived rhabdomyosarcoma (RMS) cell AC-RMSO1 cell line. Cells were incubated with each drug or their combination for $72 \mathrm{~h}$. Viability was determined with the WST-8 assay. Experimental details are provided in the Materials and Methods. (A) Growth inhibitory activity of CAF against AC-RMSO1 cells. (B) Growth inhibitory activity of VPA against AC-RMSO1 cells. (C) Growth inhibitory activity of CAF in combination with VPA against AC-RMSO1 cells.

The $\mathrm{IC}_{50}$ for VPA for AC-UPS01 was $9.54 \pm 1.44 \mathrm{mM}$. The $\mathrm{IC}_{50}$ for VPA for AC-RMS01 was $2.13 \pm 0.20 \mathrm{mM}$. The AC-RMS01 cell line was approximately 4 times more sensitive to VPA than the AC-UPS01 cell line $(p<0.00001)$ (Table I).
Table I. IC 50 values of valproic acid (VPA) and caffeine (CAF) on patient-derived cell lines: AC-UPSO1 derived from an undifferentiated pleomorphic sarcoma (UPS) (14) and AC-RMSO1 derived from a rhabdomyosarcoma (RMS) (15).

\begin{tabular}{lll}
\hline & VPA $(\mathrm{mM})$ & \multicolumn{1}{c}{$\mathrm{CAF}(\mathrm{mM})$} \\
\hline AC-UPS01 & $9.54 \pm 1.44$ & $2.02 \pm 0.22$ \\
AC-RMS01 & $2.13 \pm 0.20^{*}$ & $2.37 \pm 0.48^{* *}$ \\
\hline
\end{tabular}

${ }^{*} p<0.00001 ;{ }^{* *} p=0.1045$.

Table II. CI value of the combination of CAF and VPA against ACUPSO1 and AC-RMSO1 patient-derived sarcoma cell lines.

\begin{tabular}{|c|c|c|}
\hline $\mathrm{CAF}(\mathrm{mM})$ & $\begin{array}{l}\text { AC-USP01 } \\
\text { VPA (mM) }\end{array}$ & CI value \\
\hline $\begin{array}{l}0.25 \\
0.5 \\
1 \\
2.5 \\
5\end{array}$ & $\begin{array}{l}0.3 \\
0.3 \\
0.3 \\
0.3 \\
0.3\end{array}$ & $\begin{array}{l}0.86322 \\
0.83626 \\
0.90267 \\
0.90526 \\
0.64769\end{array}$ \\
\hline $\mathrm{CAF}(\mathrm{mM})$ & $\begin{array}{l}\text { AC-USP01 } \\
\text { VPA (mM) }\end{array}$ & CI value \\
\hline $\begin{array}{l}0.25 \\
0.5 \\
1 \\
2.5 \\
5\end{array}$ & $\begin{array}{l}0.6 \\
0.6 \\
0.6 \\
0.6 \\
0.6\end{array}$ & $\begin{array}{l}0.43371 \\
0.48922 \\
0.63914 \\
0.75918 \\
0.61738\end{array}$ \\
\hline CAF (mM) & $\begin{array}{l}\text { AC-RMS01 } \\
\text { VPA (mM) }\end{array}$ & CI value \\
\hline $\begin{array}{l}0.25 \\
0.5 \\
1 \\
2.5\end{array}$ & $\begin{array}{l}0.3 \\
0.3 \\
0.3 \\
0.3\end{array}$ & $\begin{array}{l}0.74768 \\
0.76929 \\
0.84666 \\
1.04783\end{array}$ \\
\hline CAF (mM) & $\begin{array}{l}\text { AC-RMS01 } \\
\text { VPA (mM) }\end{array}$ & $\mathrm{CI}$ value \\
\hline $\begin{array}{l}0.25 \\
0.5 \\
1 \\
2.5\end{array}$ & $\begin{array}{l}0.6 \\
0.6 \\
0.6 \\
0.6\end{array}$ & $\begin{array}{l}0.70707 \\
0.79709 \\
0.88777 \\
0.93621\end{array}$ \\
\hline
\end{tabular}

Efficacy of the combination of CAF and VPA on patientderived UPS and RMS cells. To evaluate the potential synergistic efficacy of CAF and VPA acid, the CI values were determined with WST-8. Addition of $0.3 \mathrm{mM}$ or $0.6 \mathrm{mM}$ VPA to varying concentrations of CAF enhanced efficacy against both the AC-UPS01 and AC-RMS01 cell lines (Tables II, Figure 1C, Figure 2C). The CI values were significantly $<1$ and revealed synergy at all tested concentrations in the UPS and RMS cell lines (Table II). 
In a previous study, both VPA and CAF caused concentration-dependent cell death of long-established, highpassage human osteosarcoma cell lines in vitro. The combination of VPA and CAF was also effective on the cell lines when the cell lines were implanted in nude mice. The combination of VPA and CAF showed effective anti-tumor activity in vivo without the need for conventional anticancer drugs and without any observable toxicity (6).

In the present study, CAF and VPA showed strong synergistic efficacy against low-passage patient-derived UPS and RMS cell lines, suggesting the potential future clinical efficacy of these compounds for recalcitrant sarcoma. It is interesting to note, although the two cell lines from different types of sarcoma have a similar sensitivity to CAF, the UPS cell line was much more resistant to VPA. These results indicate the importance of testing cell lines derived from patients for individual sensitivity to various agents being considered for present or future therapy.

The importance of using low-passage patient-derived cell lines for basic and translational cancer research should be emphasized.

This report is the first description of testing patientderived UPS and RMS cell lines for sensitivity to CAF and VPA. Such testing can lead to the more effective use of these compounds in the clinic and for novel effective drug discovery in the future.

\section{Dedication}

This paper is dedicated to the memory of A.R. Moossa, M.D., and Sun Lee, M.D.

\section{Conflicts of Interest}

None of the Authors have any conflict of interest in regard to this study.

\section{References}

1 Miwa S, Sugimoto N, Yamamoto N, Shirai T, Nishida H, Hayashi K, Kimura H, Takeuchi A, Igarashi K, Yachie A and Tsuchiya H: Caffeine induces apoptosis of osteosarcoma cells by inhibiting AKT/mTOR/S6K, NF-kB and MAPK pathways. Anticancer Res 32: 3643-3649, 2012.

2 Miwa S, Yano S, Tome Y, Sugimoto N, Hiroshima Y, Uehara F, Mii S, Kimura H, Hayashi K, Efimova EV, Fujiwara T, Tsuchiya H and Hoffman RM: Dynamic color-coded fluorescence imaging of the cellcycle phase, mitosis, and apoptosis demonstrates how caffeine modulates cisplatinum efficacy. J Cell Biochem 114: 2454-2460, 2013.

3 Issa JP, Garcia-Manero G, Huang X, Cortes J, Ravandi F, Jabbour E, Borthakur G, Brandt M, Pierce S and Kantarjian HM: Results of phase 2 randomized study of low-dose decitabine with or without valproic acid in patients with myelodysplastic syndrome and acute myelogenous leukemia. Cancer 121: 556-561, 2015.

4 Berghmans T, Lafitte JJ, Scherpereel A, Ameye L, Paesmans M, Meert AP, Colinet B, Tulippe C, Willems L, Leclercq N, Sculier JP and European Lung Cancer Working Party: VAC chemotherapy with valproic acid for refractory/relapsing small cell lung cancer: a phase II study. ERJ Open Res 1: 00029-2015, 2015.
5 Krauze AV, Myrehaug SD, Chang MG, Holdford DJ, Smith S, Shih J, Tofilon PJ, Fine HA and Camphausen K: Phase 2 study of concurrent radiation therapy, temozolomide, and the histone deacetylase inhibitor valproic acid for patients with glioblastoma. Int J Radiat Oncol Biol Phys 92: 986-992, 2015.

6 Happold C, Gorlia T, Chinot O, Gilbert MR, Nabors LB, Wick W, Pugh SL, Hegi M, Cloughesy T, Roth P, Reardon DA, Perry JR, Mehta MP, Stupp R and Weller M: Does valproic acid or levetiracetam improve survival in glioblastoma? A pooled analysis of prospective clinical trials in newly diagnosed glioblastoma. J Clin Oncol 34: 731-739, 2016.

7 Igarashi K, Yamamoto N, Hayashi K, Takeuchi A, Kimura H, Miwa S, Hoffman RM and Tsuchiya H: Non-toxic efficacy of the combination of caffeine and valproic acid on human osteosarcoma cells in vitro and in orthotopic nude-mouse models. Anticancer Res 36: 4477-4482, 2016.

8 Karita M, Tsuchiya H, Yamamoto N, Shirai T, Hayashi K and Nishida H: Caffeine-potentiated chemotherapy for clear cell sarcoma: a report of five cases. Int J Clin Oncol 18: 33-37, 2013.

9 Kimura H, Tsuchiya H, Shirai T, Nishida H, Hayashi K, Takeuchi A, Ohnari I and Tomita K: Caffeine-potentiated chemotherapy for metastatic osteosarcoma. J Orthop Sci 14: 556-565, 2009.

10 Kawahara M, Takahashi Y, Takazawa K, Tsuchiya H, Tomita K, Yokogawa $\mathrm{K}$ and Miyamoto K: Caffeine dose-dependently potentiates the antitumor effect of cisplatin on osteosarcomas. Anticancer Res 28: 1681-1685, 2008.

11 Tsuchiya $\mathrm{H}$, Tomita $\mathrm{K}$, Mori $\mathrm{Y}$, Asada $\mathrm{N}$ and Yamamoto $\mathrm{N}$ : Marginal excision for osteosarcoma with caffeine assisted chemotherapy. Clin Orthop Relat Res 358: 27-35, 1999.

12 Tsuchiya H, Yasutake H, Yokogawa A, Baba H, Ueda Y and Tomita K: Effect of chemotherapy combined with caffeine for osteosarcoma. J Cancer Res Clin Oncol 118: 567-569, 1992.

13 Tsuchiya H, Tomita K, Mori Y, Asada N, Morinaga T, Kitano S and Yamamoto N: Caffeine-assisted chemotherapy and minimized tumor excision for nonmetastatic osteosarcoma. Anticancer Res 18: 657-666, 1998.

14 Murakami T, DeLong J, Eilber FC, Zhao M, Zhang Y, Zhang N, Singh A, Russell T, Deng S, Reynoso J, Quan C, Hiroshima Y, Matsuyama R, Chishima T, Tanaka K, Bouvet M, Chawla S, Endo I and Hoffman RM: Tumor-targeting Salmonella typhimurium $\mathrm{A} 1-\mathrm{R}$ in combination with doxorubicin eradicate soft tissue sarcoma in a patient-derived orthotopic xenograft PDOX model. Oncotarget 7: 12783-12790, 2016.

15 Igarashi K, Kawaguchi K, Kiyuna T, Murakami T, Miwa S, Nelson SD, Dry SM, Li Y, Singh A, Kimura H, Hayashi K, Yamamoto N, Tsuchiya H, Eilber FC and Hoffman RM: Patientderived orthotopic xenograft (PDOX) mouse model of adult rhabdomyosarcoma invades and recurs after resection in contrast to the subcutaneous ectopic model. Cell Cycle 16: 91-94, 2017.

16 Chou TC and Martin N: CompuSyn for Drug Combinations: PC Software and User's Guide: A Computer Program for Quantitation of Synergism and Antagonism in Drug Combinations, and the Determination of $\mathrm{IC}_{50}$ and $\mathrm{ED}_{50}$ and $\mathrm{LD}_{50}$ Values, ComboSyn Inc, New Jersey, Paramus, 2005. 